\title{
Crohn's disease: risk of recurrence and reoperation in a defined population
}

\author{
S SHIVANANDA, * M L HORDIJK, $\dagger$ A S PENA, $\neq$ AND J F MAYBERRY§ \\ From the Department of Gastroenterology, University Hospital, Leiden, + Department of Internal Medicine II, \\ University Hospital (Dijkzigt), Rotterdam, The Netherlands, ${ }^{*}+$ and City and University Hospitals of \\ Nottingham§
}

summary Two hundred and ten patients with Crohn's disease (CD) were identified in an epidemiological survey of inflammatory bowel disease in the Leiden Health Care Region of the Netherlands. The survey included all patients with CD seen between 1979-1983. The duration of disease ranged from less than one year to 48 years. Of the 210 patients with $\mathrm{CD}, 118(56 \%)$ underwent surgical resection. Sixty one had an ileocaecal resection, 14 a proctocolectomy, in seven cases as a two stage procedure; 12 a segmental colectomy with end-to-end anastomosis and eight a subtotal colectomy with ileostomy. Twenty-one of these 118 patients $(18 \%)$ had recurrences requiring reoperation; in 11 because of recurrence at the anastomotic site. Life table analysis showed that after 10 years $17 \%$ of patients required further resection for recurrence and $8 \%$ for relapse. By 20 years the rate of recurrence had risen to $56 \%$. Patients over the age of 30 at first resection were at 1.5 fold greater risk of requiring further surgery than younger patients. The initial site of disease played no role in recurrence and there was no evidence that preoperative disease duration, delay in diagnosis, or late surgery had any effect on recurrence rates. This is one of the few community based studies to measure recurrence and relapse. A balanced appraisal is that surgery is not permanently curative, but the need for further resection may be lower than previously suggested.

Since the definitive description of Crohn's disease (CD) in 1932,' it has become clear that recurrence and reoperation are two central features of this disorder and its management. Recurrence and reoperation probably incur a risk of excess mortality, ${ }^{2}$ significant morbidity, and raise questions about quality of life. ${ }^{3}$

A number of studies have shown a significant recurrence of $C D$ after apparently curative resection. ${ }^{419}$ Most were based on selected populations at major referral centres and not on defined populations. The evidence they present is conflicting. It is, therefore, difficult to draw definitive conclusions about longterm prognosis which can be applied to all cases of $C D$ arising in the general population. ${ }^{20}$

Address for correspondence: Dr S Shivananda or M L Hordijk, Department of Internal Medicine II, University Hospital Dijkzigt GE, Centrale/BA 385. Dr Molewaterplein 40, 3015 GD, Rotterdam. The Netherlands.

Accepted for publication 7 November 1988.
The aim of our investigation was to record the frequency with which repeated surgical intervention was needed in an unselected population of patients with $C D$ in a defined area.

Lennard-Jones and Stalder ${ }^{4}$ in drawing attention to the analytical problems in assessing risk of recurrence in $\mathrm{CD}$, have put forward three possible definitions: (1) Symptomatic recurrence. (2) Symptomatic relapse with radiological and/or surgical evidence of recurrent disease. (3) Patients in groups 1 and 2 whose recurrent symptoms necessitated further resection of the gut and in whom pathological examination of the resected specimen showed evidence of $\mathrm{CD}$. In this study the third definition has been used.

There are semantic problems in defining recurrence. The term could include the development of new disease after resection or the relapse of persistent disease.${ }^{15}$ In this study we have looked at the need for further surgery in both categories. 


\section{Methods}

PATIENTS

Two hundred and ten patients with Crohn's disease were identified in an epidemiological study of inflammatory bowel disease (IBD) in the Leiden Health Care Region between 1979 and 1983..$^{21-23}$ The duration of disease in these patients ranged from $<1$ to 48 years from onset in 1935 to the end of 1983 .

The region has 440000 inhabitants and is served by four hospitals and we included all old and new cases of $\mathrm{CD}$ in the served population.

PATIENT DATA

Details of the patients' age, sex, year of disease onset and diagnosis, and follow up from first investigation to the end of 1983 were extracted from the records of all area hospitals and the archives of physicians and surgeons connected to them. Diagnostic verification of the presence or absence of $\mathrm{CD}$ and its distribution in the gut was made on the basis of Lennard-Jones' criteria..- Details of subsequent surgical history were recorded with dates of all operative procedures. Surgical reports and reports of the pathology of resected specimens were all reviewed. The criteria for confirmation of $C D$ in resected specimens of reoperated cases were based on the same features as used to make the initial diagnosis.

FOLLOW UP

All 210 patients admitted to the study were under regular surveillance and therefore diagnostic and treatment data from onset to the end of 1983 were available for review for all but two patients who died at home.

STATISTICAL ANALYSIS

Analysis of data on second surgical resections require standard survival data methods. Life tables of the product limit type were constructed, expressing the way in which the proportion remaining free of recurrences as defined by second resection decreased as time elapsed from the first resection.

The study population was divided into mutually exclusive, subgroups in ways, corresponding to some potentially explanatory variable laid down at the time of the primary resection. The reresection experiences of such a set of subgroups were compared by the logrank method. This compared observed events (second resections) in each group with expected numbers of events on the hypothesis that there was no real difference between subgroups; these counts of expected events taking into account varying individual follow up periods. The logrank method yielded a relative event rate (observed events divided by expected events) for each subgroup being com- pared, and a $\chi^{2}$ test for the significance of the difference between subgroups. ${ }^{52}$ sh

\section{Results}

Of 210 patients $118(56 \%)$ underwent a resection (Tables 1-3). For the whole series there were 2216 patient-years of follow up with a mean duration of $10 \cdot 6$ years from disease onset to 1983 or death. The 118 patients who underwent resection had 1529 patient-years of follow up with a mean duration of 13 years. From primary resection to the end of 1983 , second resection for recurrent discase, or death if earlier, there were 793 patient-years of follow up with a mean duration of 6.7 years (Table 1 ). Life table analysis showed that after ten years $25 \%$ of the patients required further resection. In $17 \%$ this was due to recurrent disease and in $8 \%$ due to clinical relapse of persistent discase (Figure and Table 2).

NATURE OF FIRST RESECTION

Table 3 shows that the majority of patients had an ileocaecal resection. Recurrence at the anastomotic site was the commonest reason for further surgery.

\section{RISK FACTORS}

Age

The effects of times of onset, diagnosis and first resection were examined in terms of the age of the patient and calendar year in which these events occurred. Of the 68 patient under 30 years old at onset eight required further surgery (expected value $=14)$ compared with 13 (expected value $=7)$ of the 50 patients over 30 years old at onset. This

Table 1 Distribution of number of years of follow up of 210 patients with Crohn's disease from Regio Leiden

\begin{tabular}{lccc}
\hline & & \multicolumn{2}{l}{ II8 Resected patients } \\
\cline { 3 - 4 } $\begin{array}{l}\text { Years of follow up } \\
\text { until 1983 or death }\end{array}$ & $\begin{array}{l}\text { All 210 patients } \\
\text { From onset }\end{array}$ & From onset From Ist resection \\
\hline $0-4$ & 54 & 19 & 51 \\
$5-9$ & 62 & 28 & 41 \\
$1(-14$ & 40 & 27 & 14 \\
$15-19$ & 21 & 16 & 6 \\
$20-24$ & 19 & 16 & 4 \\
$25-29$ & 11 & 10 & 2 \\
$30+$ & 3 & 2 & 0 \\
No of subjects & 210 & 118 & 118 \\
No of deaths & 5 & 4 & 4 \\
Total patient-years & 2216 & 1529 & 793 \\
$\quad$ follow-up & & $13 \cdot()(8 \cdot 0)$ & $6 \cdot 7(5 \cdot 7)$ \\
Mean (SD) & $10 \cdot 6(8 \cdot 0)$ & &
\end{tabular}

The distribution of duration of follow up from either onset of symptoms or from first resection until 31 December 1983 , second resection or death. 


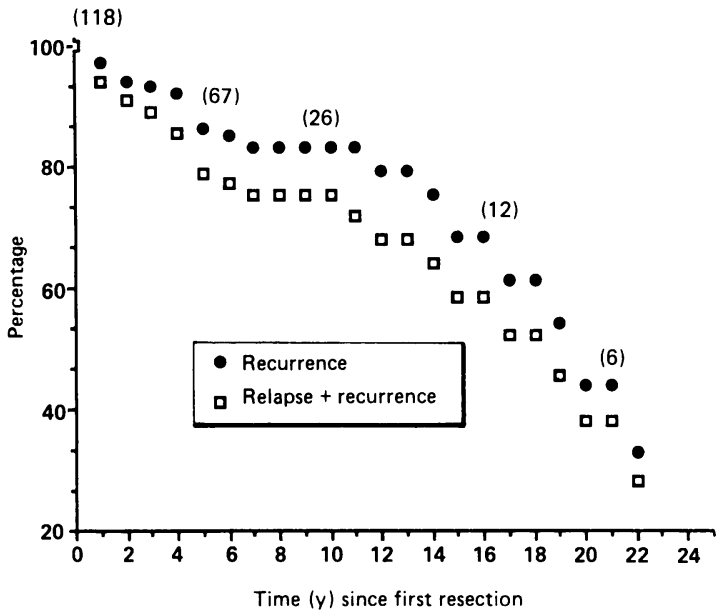

Figure Proportion of patients who have not yet had a second resection for recurrence or relapse of Crohn's disease since their initial resection. Numbers in parenthesis are the actual number of patients under observation at those times. At the beginning of the study there were 118 patients who had undergone a primary resection; 67 patients remained under observation for five years, 26 patients for 10 years, 12 for 15 years, and six for 20 years.

difference was significant $\left(\chi^{2}=6 \cdot 78 ; p<0 \cdot 01 ; \mathrm{df}=1\right)$. Similar findings occurred when the dichotomy was made around the age at diagnosis $\left(\chi^{2}=3.9 ; p<0.05\right.$; $\mathrm{df}=1)$ or age at first resection $\left(\chi^{2}=4 \cdot 2 ; \mathrm{p}<0.05\right.$; $\mathrm{df}=1)$. There was a steady trend towards increased reoperation rate with greater age.
The need for further surgery was the same for patients with onset and diagnosis in the 1980's as it had been in the 1960's.

Sex

Seven of the 53 men and 14 of the 65 women underwent a second resection compared with an expected 10.2 and 10.8 cases respectively. Although the observed/expected ratio in women was nearly twice that of men, it was not statistically significant.

DISEASE LOCATION

Six of 35 patients with small bowel disease, four of 29 with large bowel disease and 11 of 54 with small and large bowel disease underwent a second resection. There was no significant difference in the need for reoperation between patients who presented with disease at different anatomical sites.

PREOPERATIVE DISEASE DURATION AND DELAY IN DIAGNOSIS

The influence of preoperative disease duration (the interval from onset to first resection) had no significant effect on need for further surgery. Neither was there evidence that a delay in diagnosis (the interval from onset to diagnosis) nor a delay in surgical treatment of the initial disease were associated with greater risk of recurrence.

OPERATIVE PROCEDURES

Although different primary surgical procedures were associated with different risks of needing further

Table 2 Probability of not undergoing further resection for recurrence or relapse, by number of years from first resection. All patients; sexes, sites, age at first resection under and over 30

\begin{tabular}{|c|c|c|c|c|c|c|c|c|}
\hline $\begin{array}{l}\text { Time (year) } \\
\text { since first } \\
\text { resection }(t)\end{array}$ & $\begin{array}{l}\text { Whole series } \\
(n=I 18)\end{array}$ & $\begin{array}{l}\text { Men } \\
(n=53)\end{array}$ & $\begin{array}{l}\text { Women } \\
(n=65)\end{array}$ & $\begin{array}{l}\text { Small bowel } \\
(n=35)\end{array}$ & $\begin{array}{l}\text { Large bowel } \\
(n=29)\end{array}$ & $\begin{array}{l}\text { Small and } \\
\text { large bowel } \\
(n=54)\end{array}$ & $\begin{array}{l}\text { Age under } 30 \\
(n=50)\end{array}$ & $\begin{array}{l}\text { Age 30+ } \\
(n=68)\end{array}$ \\
\hline 0 & 0.992 & 0.981 & 1 & 1 & 0.966 & 1 & 1 & 0.985 \\
\hline 1 & 0.940 & 0.925 & 0.952 & 1 & 0.862 & 0.943 & 0.980 & 0.910 \\
\hline 2 & 0.910 & 0.925 & 0.897 & 0.929 & 0.862 & 0.922 & 0.957 & 0.875 \\
\hline 3 & $(0 \cdot 889$ & $0 \cdot 878$ & 0.897 & 0.929 & $0 \cdot 817$ & 0.901 & 0.957 & 0.836 \\
\hline 4 & (). 854 & 0.825 & 0.877 & 0.886 & 0.762 & 0.878 & 0.884 & $0 \cdot 8.36$ \\
\hline 5 & 0.785 & 0.796 & 0.773 & 0.886 & 0.610 & 0.803 & 0.853 & 0.735 \\
\hline 6 & $0 \cdot 770$ & 0.796 & 0.74 .5 & 0.831 & 0.610 & 0.803 & 0.853 & $0.7(03$ \\
\hline 7 & $0 \cdot 750$ & 0.796 & $(0.709$ & 0.831 & $0 \cdot 610$ & 0.766 & 0.818 & 0.703 \\
\hline 11 & 0.716 & 0.723 & 0.709 & 0.831 & $0 \cdot 610$ & $(0.711$ & 0.818 & 0.625 \\
\hline 12 & 0.678 & 0.651 & 0.709 & 0.665 & $0 \cdot 610$ & $(0.711$ & 0.818 & 0.536 \\
\hline 14 & 0.638 & 0.579 & 0.709 & 0.499 & $0 \cdot 610$ & 0.711 & 0.818 & 0.429 \\
\hline 15 & 0.585 & 0.579 & 0.608 & 0.499 & 0 & 0.711 & 0.818 & $0 \cdot 321$ \\
\hline 17 & 0.520 & 0.463 & 0.608 & 0.499 & & 0.622 & 0.701 & $0 \cdot 321$ \\
\hline 19 & 0.455 & 0.463 & 0.456 & 0.499 & & 0.534 & $0 \cdot 701$ & $0 \cdot 161$ \\
\hline 20 & $0 \cdot 379$ & 0.463 & $0 \cdot 304$ & & & 0.444 & 0.561 & $0 \cdot 161$ \\
\hline 22 & $0 \cdot 284$ & $0 \cdot 231$ & $0 \cdot 304$ & & & $0 \cdot 333$ & $0 \cdot 374$ & $0 \cdot 161$ \\
\hline
\end{tabular}

No data are presented for $8,9,10,13,16,18$, and 21 years after first resection as no second resections were undertaken at these intervals and consequently there would be no change in the probability of reoperation during those years. 
Table 3 Nature of first and second surgical procedures for recurrence in 118 patients at the end of 1983

\begin{tabular}{|c|c|c|c|c|c|c|c|c|}
\hline \multirow[b]{2}{*}{ Nature of Ist resection } & \multicolumn{8}{|c|}{ 2nd resection } \\
\hline & $n$ & $\begin{array}{l}\text { Observed } \\
(n)\end{array}$ & $\begin{array}{l}\text { Subtotal } \\
\text { colectomy }+ \\
\text { ileorectal } \\
\text { anastomosis }\end{array}$ & $\begin{array}{l}\text { Right } \\
\text { hemico- } \\
\text { lectomy }\end{array}$ & $\begin{array}{l}\text { Resection at } \\
\text { anastomosis }\end{array}$ & $\begin{array}{l}\text { Large } \\
\text { segmental } \\
\text { resection }\end{array}$ & $\begin{array}{l}\text { Procto- } \\
\text { colectomy }\end{array}$ & $\begin{array}{l}\text { Expected } \\
(n)\end{array}$ \\
\hline Partial ileal resection & 7 & 0 & - & - & - & - & - & $0 \cdot 8$ \\
\hline Ileocaecal resection & 61 & 13 & 1 & 3 & 9 & - & - & $11 \cdot 8$ \\
\hline $\begin{array}{l}\text { Ileocaecal resection with } \mathrm{R} \\
\text { hemicolectomy }\end{array}$ & 7 & 3 & 1 & - & 2 & - & - & $1 \cdot 6$ \\
\hline $\begin{array}{l}\text { Segmental colectomy with } \\
\text { end-to-end anastomosis }\end{array}$ & 12 & 3 & 1 & - & - & 1 & 1 & $3 \cdot 1$ \\
\hline $\begin{array}{l}\text { Subtotal colectomy with } \\
\text { ileostomy }\end{array}$ & 8 & 0 & - & - & - & - & - & 0 \\
\hline $\begin{array}{l}\text { Subtotal colectomy with ileo- } \\
\text { rectal anastomosis }\end{array}$ & 8 & 2 & - & - & - & - & 2 & $0 \cdot 8$ \\
\hline Proctocolectomy* & 14 & 0 & - & - & - & - & - & 0 \\
\hline Rectal excision (proctectomy) & 1 & 0 & - & - & - & - & - & 0 \\
\hline Total & 118 & 21 & 3 & 3 & 11 & 1 & 3 & 21 \\
\hline
\end{tabular}

* Of these 14 patients seven had a two stage procedure. Initially they underwent a subtotal colectomy with ileostomy and the second stage was excision of the rectum. This did not represent recurrent disease, and was not included in that analysis. It has been included in the analysis of recurrent disease and relapse (Table 1). These patients required a second surgical procedure as disease persisted and was symptomatic.

Diversion of the faecal stream failed to produce a clinical improvement.

surgery (Table 3 ) the number of events studied was small and when shared among seven or eight subgroups expected frequencies were very small and there was no statistically significant difference between categories.

\section{Discussion}

The principal conclusion drawn from our study is that
Crohn's disease may recur after apparently curative resection but the risk may be much lower than reported from referral centres. Our study shows that within 10 years of first resection up to $17 \%$ of patients may require further surgery because of recurrent disease (Table 4). In a further $8 \%$ clinical relapse may lead to reoperation. Although longterm follow up is based on relatively small numbers, these data provide useful information for patients and their

Table 4 Studies on recurrence and reoperation in selected and defined populations

\begin{tabular}{|c|c|c|c|c|c|c|c|c|c|c|c|c|c|c|c|c|}
\hline \multirow[b]{3}{*}{ Authors } & \multirow{2}{*}{\multicolumn{3}{|c|}{ Study description }} & \multirow{3}{*}{$\begin{array}{l}\text { No and }(\% \\
\text { submitted } \\
\text { to first } \\
\text { resection }\end{array}$} & \multirow{3}{*}{$\begin{array}{l}\text { No and }(\%) \\
\text { submitted } \\
\text { to further } \\
\text { resection }\end{array}$} & \multicolumn{11}{|c|}{$\begin{array}{l}\text { Cumulative rates of recurrence at five to } 20 \text { years after } \\
\text { first resection under different definitions of recurrence }\end{array}$} \\
\hline & & & & & & \multicolumn{3}{|c|}{$\begin{array}{l}\text { Symptomatic } \\
\text { recurrence }\end{array}$} & \multicolumn{4}{|c|}{$\begin{array}{l}\text { Radiologicall } \\
\text { surgical }\end{array}$} & \multicolumn{4}{|c|}{$\begin{array}{l}\text { Surgical and } \\
\text { histopathologic }\end{array}$} \\
\hline & Type & $\begin{array}{l}\text { Specified } \\
\text { period }\end{array}$ & $\begin{array}{l}\text { Patient } \\
\text { population }\end{array}$ & & & 5 & 10 & 15 & 5 & 10 & 15 & 20 & 5 & 10 & 15 & 20 \\
\hline Lennard-Jones and Stalder & $\mathrm{RC}$ & $1947-64$ & ns & $78-$ & $12(15)$ & 39 & 58 & & 28 & 51 & & & 21 & $26 \ddagger$ & & \\
\hline de Dombal et al & $\mathrm{RC}$ & $1939-68$ & 332 & $182(55)$ & $36(20)$ & & & & 20 & 34 & 4.5 & 50 & & & & \\
\hline Greenstein et $\mathrm{l}^{\circ}$ & $\mathrm{RC}$ & $1964-73$ & 160 & $100(63)$ & $58(58)$ & 60 & 81 & 94 & 4.5 & 70 & 85 & & & & & \\
\hline Hellers & DP & $1955-74$ & 826 & $506(61)$ & $253(50)$ & & & & 30 & 50 & 60 & & & & & \\
\hline Higgens and Allan" & $\mathrm{RC}$ & $1944-78$ & 227 & $199(88)$ & $96(48)$ & & & & & & & & 18 & 37 & 52 & $55 \ddagger$ \\
\hline Lock et $a l^{4 *}$ & $\mathrm{RC}$ & $1955-73$ & 1089 & $361(33)$ & $123(34)$ & & & & & & & & 20 & 35 & 42 & 48 \\
\hline Agrez et al"' & DP & $1935-75$ & 103 & $36(35)$ & $8(22)$ & & & & & & & & 40 & 55 & 60 & 70 \\
\hline Lindhagen et al" & DP & $1958-74$ & 207 & $170(82)$ & $56(33)$ & & & & & & 53 & & & & & \\
\hline Frikker et al ${ }^{12}$ & $\mathrm{CH}$ & $1965-75$ & 213 & $105(49)$ & $28(27)$ & & & & & & & & 22 & 30 & 45 & \\
\hline Goligher ${ }^{16}$ & $\mathrm{RC}$ & $1959-79$ & ns & $212-$ & $56(25)$ & & & & & & & & 8 & 15 & $20 \dagger$ & \\
\hline Whelan et al ${ }^{17 *}$ & $\mathrm{RC}$ & $1966-69$ & 615 & $438(71)$ & $209(48)$ & & & & & & & & 37 & 58 & 70 & \\
\hline Harper et $a^{14 *}$ & $\mathrm{RC}$ & $<1965$ & 621 & $122(20)$ & $89(73)$ & & & & & & & & 41 & 6.5 & & \\
\hline Shivananda et al & DP & $1935-83$ & 210 & $118(56)$ & $21(18)$ & & & & & & & & 14 & 17 & 32 & 56 \\
\hline
\end{tabular}

$\mathrm{RC}=$ referral centre; $\mathrm{DP}=$ defined population; $\mathrm{CH}=$ community hospital. ${ }^{*}=$ These three studies are all based at the Cleveland $\mathrm{Clinic}$ Foundation, Ohio. Harper et $a l^{10}$ included patients who underwent bypass procedures in their study. Patient population: number of patients diagnosed, treated or hospitalised during a specificd period from which the surgical population is drawn. ns $=$ not stated. $\dagger=$ rates refer only to patients with colectomy and ileorectal anastomosis as primary operation. $\ddagger=$ rates refer to patients with disease of the distal ileum only. 
doctors on the risk of reoperation in CD.

Are there any factors which predispose to early recurrence and reoperation? Age at onset, diagnosis and first resection, preoperative disease duration, site of disease, and type of primary surgery have all been investigated. Some believe age plays no role,$^{4812}$ whereas others feel younger patients are at greater risk. ${ }^{5710}$ Our study is the first to suggest older patients are at greatest risk of reoperation. This may reflect differences in national practise which varies from individual to individual, apart from country to country.

There have been no consistent reports that a particular anatomic site of disease is associated with a greater risk of recurrence..$^{5-7911-131719} \mathrm{We}$ found all sites to be at equal risk.

Preoperative disease duration appeared to play no part in reoperative rates. This is in contrast with de Dombal et al ${ }^{5}$ and Higgins and Allan. ${ }^{8}$ Our findings are in agreement with those of Lindhagen $e t a l^{11}$ who have shown that the risk of recurrence is not influenced favourably by early surgical intervention.

We feel that recurrence as such is not an ideal criterion upon which to base a judgment for longterm prognosis. Recurrence and relapse which require reoperation have greater prognostic value for the physician and may determine the quality of life for the patient. ${ }^{57-29}$ As Feinstein has aptly argued, it is the 'functional consequences in the severity of disease, rather than its pathologic essence, that are usually the reasons why most patients are treated or hospitalised. ${ }^{30}$ The message from all these reports has been that Crohn's disease does recur but this community based study has shown that the risk at 10 years may be much less than is generally supposed.

The authors wish to thank Robert Newcombe PhD from the Department of Medical Computing and Statistics, Coleg Meddygaeth Prifysgol Cymru (University of Wales College of Medicine) Cardiff, Wales, for statistical advice and colleagues of the Department of Internal Medicine II University Hospital (Dijkzigt) Rotterdam for providing facilities for scientific research and writing.

\section{References}

1 Crohn BB, Ginzburg L, Oppenheimer GD. Regional ileitis. A pathologic and clinical entity. JAMA 1932; 99: 1323-9.

2 Truelove SC, Pena AS. Course and prognosis of Crohn's disease. Gut 1976; 17: 192-201.

3 Gazzard BG. Quality of life in Crohn's disease. Gut 1987; 28: 378-81.

4 Lennard-Jones JE, Stalder GA. Prognosis after resection of chronic regional ileitis. Gut 1967; 8: 332-6.
5 de Dombal FT, Burton I, Goligher JC. Recurrence of Crohn's disease after primary excisional surgery. Gut 1971; 12: 519-27.

6 Greenstein AJ, Sachar DB, Pasternack BS, Janowitz HD. Reoperation and recurrence in Crohn's colitis and ileocolitis. N Engl J Med 1975; 293: 685-90.

7 Hellers G. Crohn's disease in Stockholm county 195574. A study of epidemiology, results of surgical treatment and long-term prognosis. Acta Chir Scand 1979; 490 [suppl]: 31-70.

8 Higgens C, Allan RN. Crohn's disease of the distal ileum. Gut 1980; 21: 933-40.

9 Lock MR, Farmer RG, Fazio VW, Jagelman DGM, Lavery IC, Weakley FL. Recurrence and reoperation for Crohn's disease. The role of disease location in prognosis. N Engl J Med 1981; 304: 1586-8.

10 Agrez MV, Valente RM, Pierce W, Melton LJ, van Heerden JA, Beart RW. Surgical history of Crohn's disease in a well-defined population. Mayo Clin Proc 1982; 57: 747-52.

11 Lindhagen T. Crohn's disease in a defined population. Results of surgical treatment [Thesis]. University of Lund, Malmö General Hospital, Malmö, Sweden: 1982.

12 Sachar DB, Wolfson DM, Greenstein AJ, Goldberg J, Styczynski R, Janowitz HD. Risk factors for postoperative recurrence of Crohn's disease. Gastroenterology 1983; 85: 917-21.

13 Frikker MJ, Segall MM. The resectional reoperation rate for Crohn's disease in a general community hospital. Dis Colon Rectum 1983; 26: 305-9.

14 Rutgeerts P, Geboes K, Vantrappen G, Kerremans R, Coenegrachts JL, Coremans G. Natural history of recurrent Crohn's disease at the ileocolonic anastomosis after curative surgery. Gut 1984; 25: 665-72.

15 Lee ECG. Crohn's Workshop. A global assessment of Crohn's disease. London: HM \& M Publishers, 1981.

16 Goligher JC. The long-term results of excisional surgery for primary and recurrent Crohn's disease of the large intestine. Dis Colon Rectum 1985; 28: 51-5.

17 Whelan G, Farmer RG, Fazio VW, Goormastic M. Recurrence after surgery in Crohn's disease. Gastroenterology 1985; 88: 1826-33.

18 Farmer RG, Whelan G, Fazio VW. Long-term followup of patients with Crohn's disease. Gastroenterology 1985; 88: 1818-25.

19 Harper PH, Fazio VW, Lavery IC, et al. The long-term outcome in Crohn's disease. Dis Colon Rectum 1987; 30: 174-9.

20 Sackett DL, Whelan G. Cancer risk in ulcerative colitis. Scientific requirements for the study of prognosis. Gastroenterology 1980; 78: 1632-5.

21 Shivananda S, Pena AS, Weterman IT, Mayberry JF, Ruitenberg EJ, Hoedemaeker PhJ. Epidemiology of Crohn's disease in Regio Leiden, the Netherlands. A population study from 1979-1983. Gastroenterology 1987; 93: 966-74.

22 Shivananda S, Pena AS, Mayberry JF, Ruitenberg EJ, Hoedemaeker $\mathrm{PhJ}$. Epidemiology of proctocolitis in the Region of Leiden, The Netherlands. A population study from 1979-1983. Scand J Gastroenterol 1987; 22: 9931002.

23 Shivananda S, Hordijk ML, Pena AS, Mayberry JF. 
Inflammatory bowel disease: One condition or two? Digestion 1987; 38: 187-92.

24 Lennard-Jones JE. Regional enteritis (Crohn's disease): definition and diagnosis. Skandia International Symposia: Regional entritis. Stockholm, 1970: 109.

25 Peto R, Pike MC, Armitage P, et al. Design and analysis of randomized clinical trials requiring prolonged observations of each patient. I. Introduction and design. Br J Cancer 1976; 34: 585-612.

26 Peto R, Pike MC, Armitage P, et al. Design and analysis of randomized clinical trials requiring prolonged observations of each patient. II. Analysis and examples. Br J Cancer 1977; 35: 1-39.
27 Krause, U. The role of surgery in Crohn's disease. $Z$ Gastroenterol 1979; 17 [suppl]: 171-8.

28 Meyers S, Walfish JS, Sachar DB, Greenstein AJ, Hill AG, Janowitz HD. Quality of life after surgery for Crohn's disease: a psychosocial survey. Gastroenterology 1980; 78: $1-6$.

29 Krause U, Ejerblad S, Bergman L. Crohn's discase. A long-term study of the clinical course in 186 patients. Scand J Gastroenterol 1985; 20: 516-24.

30 Feinstein AR. The intellectual crisis in clinical science: medaled models and muddled mettle. Perspect Biol Med 1987; 30: 215-30. 